Article

\title{
Residents' Willingness for Centralized Biogas Production in Hebei and Shandong Provinces
}

\author{
Qiang Wang ${ }^{1,2}$, Thomas Dogot ${ }^{2}$, Guosheng Wu ${ }^{1}$, Xianlei Huang ${ }^{1}$ and Changbin Yin ${ }^{1,3, *}$ (I) \\ 1 Institute of Agricultural Resources and Regional Planning, Chinese Academy of Agricultural Sciences, \\ Beijing 100081, China; wangqiang@caas.cn (Q.W.); wuguosheng@caas.cn (G.W.); $82101181256 @$ caas.cn (X.H.) \\ 2 Department of Economics and Rural Development, Gembloux Agro-Bio Tech, University of Liège, \\ 5030 Gembloux, Belgium; thomas.dogot@uliege.be \\ 3 Research Center for Agricultural Green Development in China, Beijing 100081, China \\ * Correspondence: yinchangbin@caas.cn; Tel.: +86-10-82107944; Fax: +86-10-82109640
}

Received: 29 October 2019; Accepted: 12 December 2019; Published: 14 December 2019

check for updates

\begin{abstract}
Nowadays, in the North China Plain (NCP), most counties and suburban rural regions are promoting the "coal to gas" program under the situation of strong government support of large and medium-sized centralized biogas production (CBP) projects. This paper is aimed at the CBP projects, focuses on rural residents' "willingness to use (WTU)", "willingness to buy (WTB)" and the influencing factors for WTU/WTB. Through the analysis of rural residents from Hebei and Shandong provinces that belong to NCP in this survey, we find that $85 \%$ of respondents support the CBP program and the WTB is $63.15 \mathrm{CNY} /$ year per capita, which is much lower than the cost of rural CBP in existing survey regions. The participation of rural residents is not only a manifestation of personal and family characteristics; understanding of environmental knowledge, attitudes, and household energy practices are more important. These non-economic factors seriously affect WTU/WTB. Hence, it is necessary to appropriately increase the government revenue to such projects, strengthen government guidance and publicity, improve the environmental knowledge and attitude of rural residents and guide residents' practice. Based on a fully understanding of residents' consumption decision mechanism, we establish a financial support mechanism due to the demand response, adopt a correct calculation for financial support, such as a reasonable subsidy rate, and seek the greatest commonality of cost, financial support, and demand.
\end{abstract}

Keywords: centralized biogas production (CBP); contingent valuation method (CVM); Heckman selection model; willingness to use (WTU); willingness to buy (WTB)

\section{Introduction}

The severe fog and haze weather in winter in North China make urban and rural residents pay more attention to environmental problems [1]. Reasonable development of renewable energy, ecological agriculture, and low-carbon agriculture has great strategic significance for China's development [2,3]. Nowadays, in the North China Plain (NCP), rural regions are vigorously promoting the "coal to gas" program. The development of rural biogas production systems is also an effective supplement. From 2000 to 2010, more than 40 million rural residents installed household biogas plants, and the average of annual growth rate was $18 \%$. However, the average annual growth rate dropped rapidly to $2 \%$ after 2010 [4]. After 2012, the annual average growth rate of large and medium-sized biogas projects had exceeded 20\% [4]. In 2015, the central government suspended the household biogas subsidy policy and intensified the subsidy policy for large and medium-sized biogas simultaneously. The models of large and medium-sized biogas stations in rural regions are economically feasible and have obvious economic, ecological, energy, and social benefits [5]. In China, there is a series of documents have been 
published to promote the utilization of biomass energy [6-10]. The Chinese government aims to use around 10 billion $\mathrm{m}^{3}$ of biomass gas (biogas, biomass gasification, etc.) by 2020. By 2035, the annual utilization of biomass gas is expected to reach about 25 billion $\mathrm{m}^{3}$ [11].

At present, large and medium-sized biogas production still mainly depends on anaerobic digestion technology. Anaerobic digestion is an efficient alternative technology that combines biofuel production with sustainable waste management [12]. According to the different sources of raw materials, it can be divided into: agricultural biomass resources, forestry biomass resources, livestock and poultry manure, domestic sewage and industrial organic wastewater, and municipal solid organic waste, etc. Different biomass wastes have different gas production potentials [13]. Various technological trends exist in the biogas industry that enhance the production and quality of biogas [14-17]. Low-cost purification is also an important technical challenge, and many new technologies have emerged [17-19]. The top three European biomethane markets (Germany, United Kingdom, Sweden) and the six non-European biomethane markets (Brazil, Canada, China, Japan, South Korea, and the United States of America) are pursuing different promotional approaches and framework conditions [20]. There are challenges associated with policy, funding, technical services, sustainability, awareness, and education, which are also key factors to achieving the full potential of biogas in developing countries [21].

Rural large and medium-sized centralized biogas production (CBP) projects use agricultural waste as the main anaerobic fermentation raw material to produce biogas and provide unified biogas supply in communities such as villages and towns. They are used as energy for cooking, heating, and other purposes to improve rural residents' lives quality. The operation of the project can reduce the open burning of straw and reduce the burning of loose coal. Biogas residues and biogas slurry can replace chemical fertilizer to return to the field. It is of great help to control air pollution and reduce $\mathrm{CO}_{2}$ emissions. Therefore, the project has strong public welfare. From the perspective of the gas supply scale, China's straw biogas project is mainly medium-sized, and the huge differences between various regions cannot be ignored. The total pool capacity of the CBP project is $500 \mathrm{~m}^{3}$ to $1000 \mathrm{~m}^{3}$, the gas supply scale is generally more than 300 households [22]. There is a large number of mature CBP projects have been formed in China after years of practice, such as [3,23], etc. The large and medium-sized biogas projects are a model with ecological and economic interests, environmental benefits, and which promote sustainable development [3] The essential key points to maximize the benefits of biogas are long-term and stable running and maintenance.

From July to November in 2018, we organized a survey on the energy utilization of crop straws in Hebei and Shandong Provinces. We found that many CBP projects were not recognized or adopted by rural residents, which was not conducive to the sustainability of this project. Considering the poor economic benefits, high ecological benefits, and production costs, the biogas market price cannot be determined solely by the relationship between supply and demand [24]. As users of biogas projects, rural residents' characteristics and attitudes, including willingness to use (WTU), willingness to buy (WTB), and influencing factors for WTU/WTB [25], are relevant to the sustainability of such biogas projects. WTU means, if a centralized biogas station is constructed, with rural residents as users, do they want to use the biogas produced? WTB means, if they are willing to use the biogas produced, how much are they willing to buy? Therefore, before the decision-making of the project, and the formulation and implementation of relevant policies, a clear understanding of user characteristics is required. It is necessary to explore the sustainable development path of the biogas project from the perspective of users through the investigation for residents. It can also provide basis data for policy formulation. Currently, there are insufficient studies related to the demand pattern of the CBP project from the users' perspectives in China. In addition, it is also meaningful to analyze the demand characteristics and users' preferences in various regions.

From the perspective of stakeholders, the current main research results of surveys on the willingness of each link for biogas, such as, rural residents' willingness to participate in collective biogas investment $[26,27]$, households' willingness to accept compensation for agricultural waste recycling [28], and rural households' willingness to accept compensation for energy utilization of 
crop straw [29]. At present, there is no research about the rural residents on the willingness to use and willingness to buy for concentrated biogas production. Therefore, this paper will understand the market demand of the centralized biogas production mode from the perspective of users, and provide a reference for decision makers to expand the economic benefits of the project. This paper will successively address the following aspects: analyzing rural residents' demand and estimating their WTU/WTB, identifying the important influencing factors that affect the WTU/WTB of residents in survey regions, focusing on the impact of individual characteristics, family characteristics, and environmental knowledge, attitude, and practice on the WTU/WTB.

The contingent valuation method (CVM) has been widely used in various fields in recent years [1,30-33]. Its guiding technology (questionnaire format) used to induce respondents' maximum or minimum WTB is changing and improving $[34,35]$. It includes a bidding game, payment card, single/bilateral boundary dichotomy, and double boundary dichotomy which has developed rapidly nowadays [36,37]. Early literature on the improvement of environmental facilities obtained the equation of purchase intention from the indirect utility function, used it as the theoretical basis of the econometric model [38]. However, in the theoretical model of the indirect utility function, the random term was not included. Then Hanemann et al [39] added the random term to the indirect utility function and established the random effect, and, with the function, the theoretical framework has been improved. In addition, the early measurement equation of purchasing willingness for the construction only included socio-economic variables. However, the purchasing willingness obtained by the conditional value method is in a sense caused by non-economic factors [40]. As it is incomplete to explain purchasing willingness only by socio-economic factors [41], more and more researchers will use attitudes, knowledge and other non-economic factors $[25,42]$. These variables are introduced into the purchase intention equation, and studied with socioeconomic factors. In the study of rural residents' WTU/WTB for the CBP project, it is necessary to consider the individual characteristics, socio-economic factors, and some non-economic factors of rural residents, so we use the CVM method for research.

Assuming that rural residents' decision-making is rational [43], utility maximization [44] is the rural residents' behavioral goal, and the expected quality of life becomes the basis for their behavioral decision-making. Based on the individual and family characteristics of rural residents, the current status of household energy use, rural residents' knowledge, attitudes, and energy preference affect the rural residents' expectations from different angles, then influence their WTU/WTB. Reviewing relevant literature, although there are many articles about residents' willingness to use and willingness to pay in household energy improvement, the attempts and explorations for Chinese rural residents' WTU/WTB and influencing factors of the CBP projects are rare. This paper will estimate the WTU/WTB of CBP projects and systematically study the purchasing willingness of rural residents.

Based on the information mentioned above, this paper proposes the following hypotheses:

Hypothesis 1 (H1). Households with heavy family burdens are negatively correlated with WTU and WTB, such as families with a large size/or children.

Hypothesis 2 (H2). Environmental knowledge is positively correlated with WTU and WTB.

Hypothesis 3 (H3). Environmental attitude is positively correlated with WTU and WTB.

Hypothesis 4 (H4). The practice of household daily energy consumption is negatively correlated with WTU and WTB, that is, the higher the proportion of clean energy, the higher the WTU and WTB. 


\section{Methodology}

\subsection{Region Description}

The scope of the investigation was locked in the Hebei Province and Shandong Province (Figure 1) for the following reasons. In these regions, the rural population is dense, and loose coal is seriously used. They both are located in the hinterland of NCP, with traditional high-energy and high-pollution industries [45]. In these regions, the whole society electricity consumption and vehicle ownership also play a positive role in air pollution [46]. The region used to have the most severe air pollution in China, and even the world [47-49]. The residents in investigation regions have a deeper and clearer understanding of air pollution [50]. They are also the main grain production regions and rich in straw resources with corn and wheat planting. In 2015, the straw output of Hebei Province was 39 million tons, accounting for $5.4 \%$ of the total national output, and the straw output of Shandong Province was 56.8 million tons, accounting for $7.9 \%$ of the total national output [51]. The two provinces are also the regions where the CBP projects are relatively concentrated in China [52]. Now, there are many CBP projects that are already in a mature operation mode.

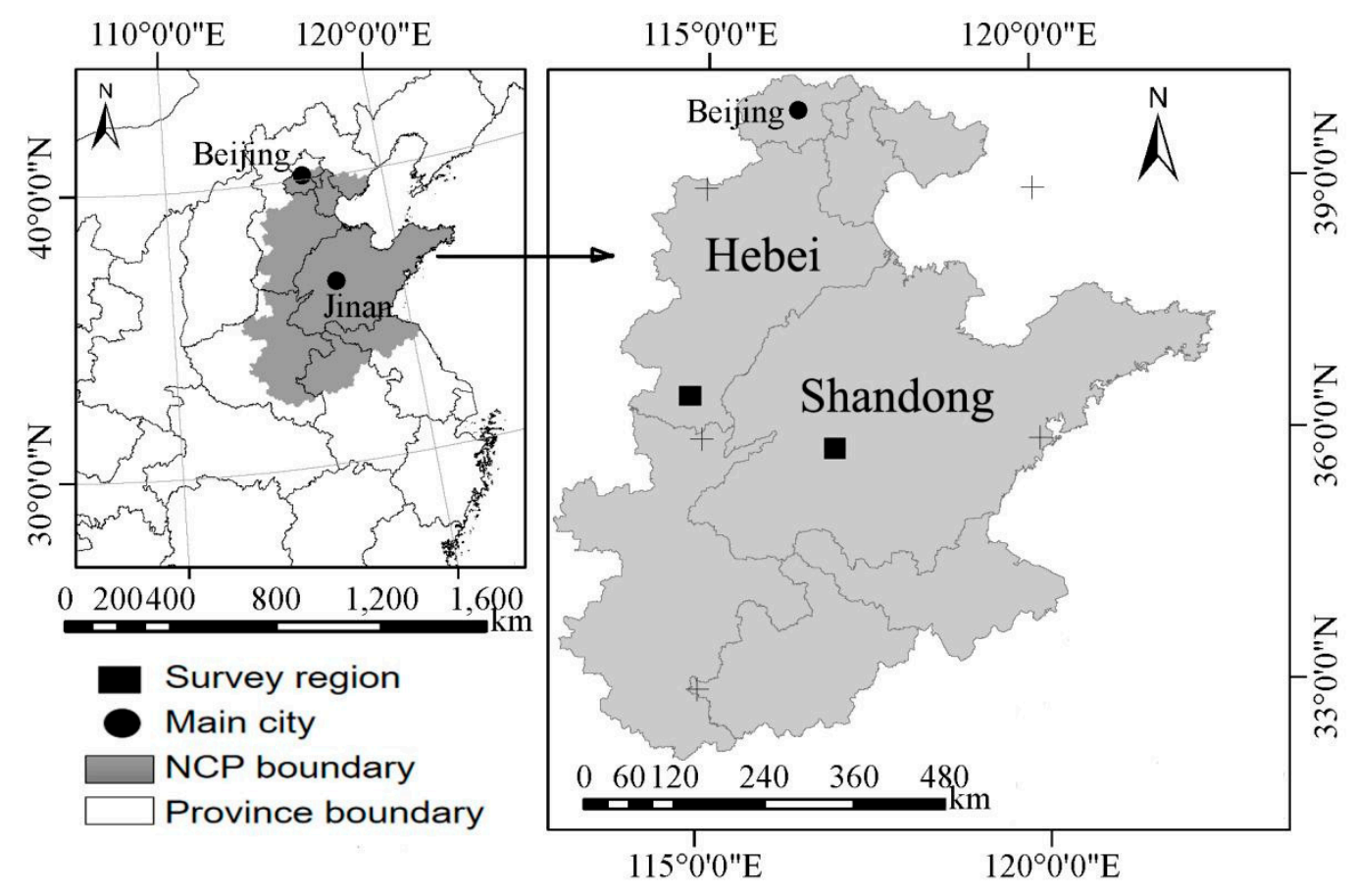

Figure 1. Location of the survey regions.

\subsection{Survey Methods}

The data were collected by a questionnaire survey on biomass utilization in rural regions of Hebei and Shandong, conducted in Daiyue District, Feicheng City, Shandong Province, Linxi County, Weixian County, and Linzhang County, Hebei Province, from July to November in 2018.

The survey includes the following aspects (Table 1).

What needs special explanation is, in recent years, KAP theory have often been used in the consumer and environmental sectors $[54,55]$. There are no clear rules on how to best conduct a KAP survey, as the methods vary according to the subject and purpose of the study [56].

The method of investigation of the residents' WTU/WTB was a combination of group, one-to-one and fixed-point random sampling. In order to ensure that the respondents fully understand the CBP mode, the researcher used 1-5 min to introduce CBP projects and models to the respondents at first. The questionnaire used the double-bounded dichotomous choice method [57-59]. It took an estimated 
$20 \mathrm{~min}$ to complete one questionnaire. The research team organized local rural residents to use in this survey by contacting the local agricultural sector.

Table 1. The definition and description of variables.

\begin{tabular}{|c|c|c|c|}
\hline \multicolumn{2}{|c|}{ Variable } & Code & Description \\
\hline \multirow{2}{*}{\multicolumn{2}{|c|}{ dependent variable }} & WTU & $\begin{array}{l}\text { If there is a centralized biogas station, do you } \\
\text { want to use the centralized biogas produced? }\end{array}$ \\
\hline & & WTB & $\begin{array}{l}\text { How much each person would like to spend on } \\
\text { concentrated biogas each year? }\end{array}$ \\
\hline \multirow{3}{*}{\multicolumn{2}{|c|}{$\begin{array}{l}\text { Individual characteristic } \\
\text { variables }\end{array}$}} & Gender & Male or female \\
\hline & & Age & Respondent's age \\
\hline & & Edu & Years of education \\
\hline \multirow{12}{*}{$\begin{array}{l}\text { independent } \\
\text { variable }\end{array}$} & \multirow{7}{*}{$\begin{array}{l}\text { Family characteristic } \\
\text { variables }\end{array}$} & Population & Number of family members \\
\hline & & Area & Area of arable land owned by family \\
\hline & & Age10 & Number of children under 10-years-old \\
\hline & & Age65 & Number of seniors over 65 -years-old \\
\hline & & Cadre & Whether to have village cadres in the family \\
\hline & & Income & Family income in 2017 \\
\hline & & Expenditure & Household expenditure in 2017 \\
\hline & \multirow{2}{*}{$\begin{array}{l}\text { Household energy } \\
\text { consumption variable }\end{array}$} & Solar & Whether to have solar water heaters? \\
\hline & & Biogas & Whether to have household biogas? \\
\hline & \multirow{3}{*}{$\mathrm{KAP}^{*}$ variable } & Knowledge & Understanding of any given topic [53] \\
\hline & & Attitude & $\begin{array}{l}\text { Feelings towards it, along with predetermined } \\
\text { opinions [53] }\end{array}$ \\
\hline & & Practice & $\begin{array}{l}\text { Ways in which they demonstrate their knowledge } \\
\text { and attitude through their actions [53] }\end{array}$ \\
\hline
\end{tabular}

* Note: "Knowledge, Attitude and Practice (KAP)" theory is a behavior intervention theory. KAP refers knowledge as "understanding of any given topic", attitude as "feelings towards it, along with predetermined opinions" and practice as "ways in which they demonstrate their knowledge and attitude through their actions" [53].

In the actual investigation process, the first question was "whether they are willing to support the CBP project under the imaginary conditions", that is, if a CBP project is built in the village to supply biogas to the residents, whether to want to use the biogas. The answer option is "1. Yes; 0. No". If the respondents answers yes, then they enter the WTB link. Before the WTB survey, the respondent was first informed that "the current city gas cost is about $3 \mathrm{CNY} / \mathrm{m}^{3}$ (CNY, Chinese Yuan "¥"), and the annual gas consumption per capita was about $180 \mathrm{CNY}$. The cost of canned liquefied gas in rural regions was basically the same. Respondents' families were willing to pay for the biogas. The amount was calculated based on the annual gas fee per capita." The answer options were: "A. 0; B. 1-60; C. 61-120; D. 121-180; E. 181-240; F. 241-300; G. 301-360; H. >361". Considering the actual cost and referring to the situation of urban residents' centralized gas supply cost, setting the highest value of 360 $\mathrm{CNY}$, the respondents were asked to spend up to $360 \mathrm{CNY} /$ year per capita, and the lowest was $0 \mathrm{CNY}$. When facing $360 \mathrm{CNY}$, the respondents expressed their support for the CBP project, they were directly asked how much they would like to pay. Finally, get the interval value of the respondent's WTB.

\subsection{Variable Definition}

For the dependent variables, the WTU/WTB are chosen separately. In the process of investigation, the investigators will make a special explanation. The purchase intention is to assume that without government subsidy, each person will pay for gas consumption annually. Referring to the current average gas consumption cost of urban residents in China, it is about $180 \mathrm{CNY} /$ year per capita (survey data, the average gas consumption of urban residents in NCP is about $60 \mathrm{~m}^{3} /$ year per capita, and the 
price is $3 \mathrm{CNY} / \mathrm{m}^{3}$ ). In the questionnaire, $180 \mathrm{CNY}$ was set as the median value, the lowest value was 0 $\mathrm{CNY}$, and the highest value was $360 \mathrm{CNY}$. If it exceeds $360 \mathrm{CNY}$, directly filling in the amount of the purchaser's WTB.

For the independent variables, most of them are directly from the inquiry of the respondent, but the independent variables mentioned below need to be processed before they can be used.

Income variables and expenditure variables: Income is a variable that is difficult to obtain accurate results for. Because the respondents cannot accurately recall and calculate or are unwilling to disclose to the respondents, there is a big deviation in the data obtained by direct inquiry income, so the survey is generally estimated by the respondents' working conditions and planting conditions. Expenditure variables are also estimated in terms of household burden, and on household durable consumer goods expenditure and so on.

The method of obtaining knowledge variable for environmental protection is as follows [54,60]: each respondent is asked 10 questions, with one point for each question, and then each question is scored according to whether the answer is correct or not, then the score of the question is added up to get the environmental protection knowledge variable.

The environmental protection attitude variable reflects the understanding of importance for environmental protection. This variable is obtained by the following methods [60]: Ask the respondents about the importance of environmental protection compared with income and health, and then let the respondents allocate between income, health, and environmental protection, assigning a total score of 10. If 3 points are allocated to environmental protection, then the respondents' attitude score is 3 points.

Household energy preference is a proxy variable used to highlight the practice of household daily energy consumption. Therefore, a preference value is given to each practice as follows: mainly clean energy, such as liquefied gas, electricity etc., we define it as 1 ; mainly traditional energy such as coal and firewood, we define it as 3; clean and traditional energy (half), we define it as 2 . The lower the preference value, the cleaner the current energy practice.

The variable settings of the Heckman selection model in this section are shown in Table 2.

Table 2. The descriptive statistics of variables.

\begin{tabular}{|c|c|c|c|}
\hline Code & Value Setting & Mean Value & Std. Dev. \\
\hline WTU & Yes $=1$ & 0.85 & 0.36 \\
\hline WTB & Unit: CNY & 66.78 & 55.19 \\
\hline Gender & 1 if male & 0.59 & 0.49 \\
\hline Age & years & 50.17 & 11.45 \\
\hline Edu & years & 7.43 & 2.98 \\
\hline Population & Number & 5.78 & 2.16 \\
\hline Area & Unit: $\mathrm{Mu}\left(\mathrm{Chinese}\right.$ land unit, $\left.1 \mathrm{mu}=666.67 \mathrm{~m}^{2}\right)$ & 12.90 & 41.74 \\
\hline Age10 & Number & 1.26 & 0.99 \\
\hline Age65 & Number & 0.73 & 0.79 \\
\hline Cadre & 1 if yes & 0.17 & 0.38 \\
\hline Income & Number & 32,205 & 24,470 \\
\hline Expenditure & Number & 20,478 & 14,851 \\
\hline Solar & 1 if yes & 0.59 & 0.49 \\
\hline Biogas & 1 if yes & 0.11 & 0.31 \\
\hline Knowledge & Score & 4.98 & 3.16 \\
\hline Attitude & Score & 3.09 & 2.12 \\
\hline Practice & $\begin{array}{c}1=\text { Mainly clean energy; } \\
2 \text { = Clean and traditional energy (half); } \\
3=\text { Mainly traditional energy such as coal and firewood; }\end{array}$ & 1.95 & 0.74 \\
\hline
\end{tabular}

Note: The willingness to buy (WTB) value of sample data is the mean value: 1 60 CNY, 30.5 CNY; 61 120 CNY,90.5 CNY; 121 180 CNY, 150.5 CNY; 181 240 CNY, 210.5 CNY; 241 300 CNY, 270.5 CNY; 301 360 CNY, 330.5 CNY;> 361 $\mathrm{CNY}$, the actual amount. 


\subsection{Descriptive Analysis}

A total of 389 questionnaires were collected in this survey. After eliminating the lack of data or filling in the contradictory questionnaires, 351 valid questionnaires were obtained. The total effective rate of the samples was $90.23 \%$.

In the regions selected by this survey, wheat and maize are the main agricultural planting regions, the level of industrial development is relatively lagged. Agricultural production (crop cultivation and livestock raising) and migrant workers are the main sources of rural residents' income in the above-mentioned regions. The weather conditions and energy habits of residents are similar among regions, the level of economic and social development among regions is comparable. In terms of the current situation of household energy use, $58.97 \%$ of households in the survey area own solar energy, only $10.54 \%$ of households occupy household small biogas, unfortunately, most of biogas are basically abandoned.

In terms of household domestic hot water energy consumption, $7.41 \%$ of respondents use liquefied gas, $11.95 \%$ of respondents use electric water heater, $51.00 \%$ of respondents mainly use coal, $11.68 \%$ of respondents use firewood, $2.28 \%$ of respondents apply biogas.

In terms of WTB, $85.19 \%$ of respondents respond positively when asked whether they would like to use gas if a biogas station was built to provide concentrated gas to residents. For users willingness to use, $16.39 \%$ of respondents still worry about the cost. This reflects that rural residents have a high enthusiasm for participating in CBP if the cost is still within the affordable range. It is not negligible that some residents are still worried about the cost. For unwilling users, $38.46 \%$ of respondents say they were accustomed to the current lifestyle and did not want to change, other $61.54 \%$ say they are worried about the cost.

The statistics of cognitive information source (multiple selections) are as follows: $48.22 \%$ of respondents choose TV $\backslash$ newspapers $\backslash$ books; $20.56 \%$ of respondents choose village committee; $13.96 \%$ of respondents choose mobile and Internet; $4.57 \%$ of respondents choose friends and relatives; $4.31 \%$ of respondents choose agricultural technology departments; $4.06 \%$ of respondents choose agricultural resources dealer; $4.31 \%$ of respondents choose others.

\subsection{Model}

In order to correct the problem of sample selection bias, the specific form of sample selection must be screened first. Considering the two-stage characteristics of this study (the first stage is a binary selection model with $0-1$ distribution, the second stage is an method of ordinary least square (OLS) model), the "Heckman selection method" is selected to deal with the problem that sample selection bias may lead to distortion of coefficient estimation in OLS estimation. The specific forms of the equation are as follows [61]:

$$
\Upsilon_{\text {WTB }}=\alpha+X_{i} \beta+\varepsilon_{i}(i=1,2, \cdots, \mathrm{n})
$$

where, $Y_{\text {ШТВ }}$ is purchasing intention, $X_{i}$ is explanatory variable row vector, $\beta$ is the corresponding independent variable coefficient column vector, and $\varepsilon_{i}$ is perturbation term and obeys standard normal distribution. Further, the observability of $\mathrm{Y}_{\text {WТВ }}$ depends on the binary selection variable $z_{i}$ : $\mathrm{Y}_{\mathrm{WTB}}$ is observable when $z_{i}=1 ; \mathrm{Y}_{\mathrm{WTB}}$ is not observable when $z_{i}=0$. It is assumed that $z_{i}^{*}$ is a potential variable of $z_{i}$, in the form of:

$$
z_{i}^{*}=B_{i} \zeta+\eta_{i}(i=1,2, \cdots, \mathrm{n})
$$

Meet

$$
z_{i}= \begin{cases}1 & z_{i}>0 \\ 0 & z_{i} \leq 0\end{cases}
$$

where, $B_{i}$ is the row vector of the independent variable, $\zeta$ is the column vector of the coefficient of the independent variable, and $\eta_{i}$ is the perturbation term. If $\eta_{i}$ obeys binary normal distribution, then $z_{i}$ is Probit model. Usually, $X_{i}$ and $B_{i}$ often contain the same independent variables, and they are highly 
correlated. Therefore, it is very possible that using OLS estimation directly at this time would lead to inconsistent estimation results. With the help of the Probit model, we can get:

$$
\bar{\lambda}=\frac{\phi\left(B_{i} \zeta / \sigma_{z}\right)}{\Phi\left(B_{i} \zeta / \sigma_{z}\right)}
$$

By taking $\bar{\lambda}$ as a modified variable into Equation (1), we can obtain that:

$$
Y_{\text {WTB }}=\alpha+X_{i} \beta+\beta_{0} \bar{\lambda}+\varepsilon_{i}(i=1,2, \cdots, \mathrm{n})
$$

On this basis, $\alpha, \beta_{0}, \beta$ can be obtained by OLS estimation. If the T value of the corrected variable $\bar{\lambda}$ is significant, it shows that the sample selection error exists and the model selection is effective; on the contrary, the Equation (1) estimation is effective. Further, if $X_{i}^{*}$ is a significant variable and $\beta^{*}$ is a corresponding significant variable coefficient, then the purchasing intention of rural residents can be expressed as follows:

$$
E\left(Y_{\text {WTB }}\right)=\alpha+X_{i}^{*} \beta^{*}+\beta_{0} \bar{\lambda}
$$

\section{Results}

\subsection{Measurement Results}

A multi-collinearity test is made for each independent variable. The mean variance inflation factors (VIF) equals to 1.75. However, the VIF of income and expenditure variables is above 3 . The multi-collinearity among the other variables is reasonable. Income represents the economic source of the family, but high income does not indicate a high disposable income. The level of expenditure shows the level of family burden. Therefore, in order to avoid multi-collinearity, the income variable is removed and only the expenditure variable is retained.

Relying on the Heckman selection model and using Stata15.0 measurement software, the regression analysis of WTU/WTB was carried out. The $\chi$ value is 32.30 , and the $p$-value is 0.0059 . The overall effect is good. The inverse Mills ratio is 54.42 , which is significant at $5 \%$ of the statistical level. This shows that there is bias in the sample, and the model selection is effective. The measurement results

\begin{tabular}{|c|c|c|c|c|c|}
\hline \multirow{2}{*}{ Classification } & \multirow{2}{*}{ Variables } & \multicolumn{2}{|c|}{ Phase1 (WTU) } & \multicolumn{2}{|c|}{ Phase2 (WTB) } \\
\hline & & Coef. & S. Error & Coef. & S. Error \\
\hline \multirow{3}{*}{$\begin{array}{c}\text { Individual } \\
\text { characteristic } \\
\text { variables }\end{array}$} & Gender & 0.17 & 0.23 & 3.90 & 7.27 \\
\hline & Age & -0.02 & 0.01 & -0.47 & 0.34 \\
\hline & Edu & 0.03 & 0.04 & 1.44 & 1.30 \\
\hline \multirow{6}{*}{$\begin{array}{c}\text { Family } \\
\text { characteristic } \\
\text { variables }\end{array}$} & Population & -0.10 & 0.06 & $-5.64 * * *$ & 2.16 \\
\hline & Area & 0.00 & 0.01 & 0.11 & 0.09 \\
\hline & Age10 & $0.40^{* * *}$ & 0.14 & $9.09 *$ & 5.27 \\
\hline & Age65 & 0.01 & 0.14 & -3.60 & 4.54 \\
\hline & Cadre & $0.65^{*}$ & 0.40 & 2.98 & 9.29 \\
\hline & Expenditure & 0.00 & 0.00 & 0.00 & 0.00 \\
\hline \multirow{2}{*}{$\begin{array}{l}\text { Life energy } \\
\text { variable }\end{array}$} & Solar & $0.53^{* *}$ & 0.23 & 11.17 & 7.57 \\
\hline & Biogas & -0.58 & 0.41 & -7.57 & 11.39 \\
\hline \multirow{5}{*}{ "KAP" variable } & Knowledge & $0.13^{* * *}$ & 0.04 & $2.57^{*}$ & 1.35 \\
\hline & Attitude & $0.24^{* * *}$ & 0.07 & $4.95^{* *}$ & 2.01 \\
\hline & Practice & $-0.40 * *$ & 0.16 & $-14.56^{* * *}$ & 5.53 \\
\hline & _cons & 1.20 & 0.83 & $87.12 * * *$ & 24.90 \\
\hline & Mills(lambda) & & & $57.90^{* *}$ & 24.89 \\
\hline
\end{tabular}
are detailed in Table 3.

Table 3. Heckman selection model measurement results.

Note: Coeff. $=$ estimated coefficient. ${ }^{*}, * *, * * *$, coefficient is significant at $10 \%, 5 \%$, and $1 \%$ probability levels, respectively. Number of obs $=351$. Non-selected $=52$. Wald chi2 $(14)=29.11$. Prob $>$ chi2 $=0.0101$. 


\subsection{Result Analysis}

\subsubsection{Impacts of Individual Characteristics, Family Characteristics and Energy Characteristics}

According to this survey, considering individual characteristics, the three variables of gender, age and education have no significant influence on WTU/WTB. This indicates that the WTU/WTB in rural regions of Hebei and Shandong are not affected by the gender, age, and education of the residents.

In terms of family characteristics, "children under 10-years-old" has a significant influence on WTB, has a negative coefficient on WTU, which indicates that the child is important to a family's life improvement decision. The "over 65-years-old" is not significant, explaining that families with elderly people are not strong in their desire to improve their lives. The influence of whether there are "village cadres in the family" is also significant, the coefficient is positive, which demonstrates that families that have village cadres at home have higher WTU under other conditions. However, in terms of WTB, the family "population" and families with "children under 10-years-old" have significant impacts, but the coefficient of "population" is negative and the coefficient of children is positive. This explains that under other conditions, the more people, the heavier family burden, the lower gas bills can be loaded; the more children under the age of 10 in the family, the lower the WTB, even hoping that the government can bear more gas bills for them. This explains a Chinese proverb "Poor parents in the world".

Moving to the household energy characteristics, "households with solar water heaters" has a significant impact on the WTU with a positive coefficient, shows that households who prefer solar water heaters have a higher WTU. Households with "household biogas" has an inconspicuous influence on the WTU. This is inconsistent with the above assumptions. This is basically consistent with the information obtained in the survey. Most household biogas users respond that the biogas pool is extremely troublesome in the process of use, so many users are gradually abandoning this technology. A more important reason is that the funds for biogas construction are basically subsidized by the state and belongs to passive construction. Therefore, it is not optimistic about the prospects of biogas projects. However, for the "solar water heaters" residents, the use of solar water heater is an active behavior. In terms of WTB, the impacts of "solar water heaters" and "household biogas" are not significant, because these two factors are not related to the family's payment.

\subsubsection{Impacts of "KAP"}

Non-economic variables of environmental knowledge, attitude and practice are equally significant in WTU/WTB, and the coefficients are in the same direction. Coefficients of knowledge and attitude are positive, indicating that the higher cognitive score for environmental protection, the more positive the WTB, the higher the gas fee that is willing to buy. The more active WTB is because the attitude towards environmental protection is more concerned, the higher the gas fee that is willing to buy. The coefficient of the practice variable is negative, which shows that the cleaner the household's current living energy is, the more active the WTB and more gas fees are willing to buy. This is consistent with the findings of Whittington et al [62] on the improvement of rural water supply facilities in Brazil. That is, households who are accustomed to use liquefied gas and electricity have a greater expectation for cleaner energy and are much easier to accept the higher cost of CBP.

Cognitive theory shows that the processes or activities of people obtaining and using information are: first, perceiving information [63], then identifying the content of the information, then generating willingness, and finally changing behavior [64]. According to cognitive theory, the influence of knowledge, attitudes, and household energy preferences on the purchasing willingness of rural residents should be comprehensive. It can be interpreted from the regression results in Table 3 that the degree of awareness of environmental protection has a significant positive impact on the WTB concentrated gas, that is, the higher the awareness of environmental knowledge, the higher the WTB. Similarly, respondents' emphasis on environmental protection has also increased the willingness of rural residents to purchase concentrated gas. Results can be obtained that it is an effective measure 
to change household energy preferences and increase residents' WTB by raising public awareness of environmental awareness through publicity activities such as education and attaching importance to cultivate individual attention to environmental protection.

\subsection{Calculation of Payment Level}

The biogas fee that all participants are willing to purchase is $78.40 \mathrm{CNY} /$ year per capita According to formula (5) and Table 3, after removing sample selection bias, the expected value of rural residents' WTB is $63.15 \mathrm{CNY}$, and the average WTB per household is $365.01 \mathrm{CNY}$.

\section{Discussion}

It is necessary to establish financial support such as subsidy mechanism based on demand response in order to improve the sustainability of the project. Demand response is considered as a potentially cost-effective means [65]. Hassani et al [66] attempt to retroactively predict changes in fuel prices and demands to predict the robustness of the presented fuel subsidy mechanism. Through the results, the average maximum purchase intention of rural residents in the survey regions is far from the cost of rural CBP projects in the current survey area. The ratio of calorific value of urban natural gas to rural biogas is 0.6 (survey data). At present, the price of gas for urban residents is around $2.2 \mathrm{CNY} / \mathrm{m}^{3}$ to $4.3 \mathrm{CNY} / \mathrm{m}^{3}$ [67]. The gas fee for conversion to the same calorific value with urban natural gas is around $1.32 \mathrm{CNY} / \mathrm{m}^{3}$ to $2.58 \mathrm{CNY} / \mathrm{m}^{3}$. According to the investigation, urban residents use $60 \mathrm{~m}^{3} /$ year of natural gas, so rural residents need to use biogas $100 \mathrm{~m}^{3}$ in the case of the same calorific value. The rural residents need to pay a gas fee of 132 to $258 \mathrm{CNY} /$ year per capita according to the WTB. There is an obvious gap between WTB and gas fees that residents should pay. Consider the production cost of biogas in the field of investigation, we further understand and calculate the cost of $200 \mathrm{~m}^{3}$ to $1000 \mathrm{~m}^{3}$ medium-sized CBP stations. According to the data from the biogas engineering design data of the Chengdu Energy and Environmental Engineering Design Institute of the Ministry of Agriculture and Rural Affairs, the biogas production cost from $2.71 \mathrm{CNY} / \mathrm{m}^{3}$ to $4.18 \mathrm{CNY} / \mathrm{m}^{3}$, the cost is $271 \mathrm{CNY} /$ year to $418 \mathrm{CNY} /$ year per capita. It can be seen that there is a greater gap between the WTB and the cost of the actual operation of CBP projects.

Adopting a correct calculation of financial support, such as a reasonable subsidy rate, is the premise of the effectiveness of the financial support policy. Padilla-Rivera et al [68] thought that sustainability assessment of bioenergy was necessary when developing energy policy and technology roadmaps. Shih et al [69] proposed that differentiated subsidy rates were an efficient mechanism for environmental protection. At present, China has no unified subsidy standard for CBP projects in various places [70,71]. If only the gap between WTB and gas bills is considered, the subsidy rate is $52.16-75.52 \%$ of the gas bills. However, if we further consider the gap between WTB and production costs, the subsidy rate will reach $76.70-84.89 \%$ of the production cost. This level of clean energy subsidies is far from the United States, the European Union, etc. [72,73]. So, for the huge ecological benefits of the project, it is necessary to comprehensively consider the project production costs and the price of product and WTB, and to establish a sustainable development mechanism for project break-even to ensure the sustained development of the project.

Changes in the household characteristics of residents will affect WTU/WTB. This is basically consistent with the conclusion of Zeng et al., and Zou and Luo [74,75]. With the miniaturization of the Chinese family's size, the relaxation of family planning policies and the improvement of rural residents' education will lead to an increase of rural residents' WTB in the future. Rural residents' WTB is limited by socioeconomic characteristics such as the number of family members and number of children in the family. According to the Report on the family development in China [76], China is already a country with a small average family size, with the liberalization of the birth of a second child per family, the increase in the level of rural education [67] will enhance the rural residents' WTB. The gap between rural residents' WTB and subsidy rates will be further narrowed. Therefore, from these socio-economic characteristics, the rural residents' WTB will gradually be higher. 
Interestingly, based on the above assumptions, income and expenditure should also be a reference to reflect the burden of the family, but the impact is not significant. In the field research, we also find that the respondents basically take the household coal consumption as a reference when answering the interview questions. The energy consumption accounts for the low proportion of local rural residents' total income and total consumption. It accounts for only $1.13 \%$ of local rural residents' household income and $1.78 \%$ of household expenditure. According to the Chinese Residential Energy Consumption Survey 2013 (CRECS 2013), coal accounts for about 15.1\% [77]. According to the Chinese General Social Survey 2015 (CGSS 2015), coal accounts for about 11\% [58]. In 2016, the average household expenditure on electricity, gas, and coal are 910 CNY, 300 CNY, and 420 CNY [78], respectively

In 2018, the per capita disposable income of rural regions in Shandong Province was 16,297 CNY, and the per capita consumption expenditure was 11,270 CNY [79]. The per capita disposable income of rural regions in Hebei Province was 14031, and the per capita consumption expenditure was 11,383 CNY [80]. If following the average data in the government gazette, the ratio is lower. Studying the impact of income and expenditure structures on WTU/WTB may be a direction that needs to be analyzed.

The residents' WTU/WTB are not only the embodiment of individual and family characteristics but more importantly to the recognition of environmental knowledge, attitudes and the practice of household daily energy consumption. Babaei et al [81] had similar findings in assessing the relationship between KAP and the willingness to pay for solid waste services. The results of empirical analysis show that education on environmental protection knowledge of rural residents can significantly improve the willingness of people to purchase concentrated gas, thus expanding the penetration rate and utilization rate of CBP. In addition to the level of environmental awareness, residents' attitude toward environmental protection is also a major factor affecting their purchasing willingness. This article reflects residents' attitudes toward environmental protection by comparing the importance of income, health, and environmental protection in the hearts of respondents. The results of the metro-logical analysis indicate that the attitude of environmental protection has a significant positive impact on the residents' WTB. Household energy preferences also have a significant positive impact on residents' WTB. Therefore, non-economic factors such as environmental awareness, environmental protection attitude, and household energy preference have considerable impacts on residents' WTU/WTB. Therefore, work should be carried out focusing on these non-economic factors to improve the KPA of residents. Through improving these non-economic factors, it would improve the residents' WTU/WTB [82]. Environmental education is an important way to enhance the non-economic factors [83,84]. Environmental education should be focused on the following channels: TV, newspapers, books, village committee, mobile, and Internet.

What needs special explanation is, according to the above assumptions, households equipped with household biogas should be a high proportion of clean energy households, but WTU/WTB are not significant. This is related to the special national conditions in China. The household biogas construction is the passive demand behavior mainly driven by government subsidies in China $[85,86]$. This also shows that the financial support of the construction process is only part of the promotion process, and continuous support for user needs in the daily operation process is more important. At the same time, it is necessary to fully understand the user's active demand behavior based on WTU/WTB and distinguish passive demand behavior. Especially the identification of some non-economic factors, so as to guide the needs of users and achieve sustainable development of the project.

\section{Conclusions}

Based on the survey data collected in Hebei and Shandong in 2018, this study estimated rural residents' WTU/WTB for CBP projects and determined the factors affecting rural residents' decision-making. Although $85 \%$ of the respondents support the CBP project, there is a huge gap between rural residents' WTB and actual production costs. The high proportion of WTU is mainly due to a series of administrative measures currently taken for environmental governance $[6,87]$. 
The gap between WTB and gas bills, and WTB and production costs are still very obvious. The family characteristics such as the number of family members and the number of children in the family are highly correlated with WTB. Starting from the correlated variables, WTB will gradually increase. Then, the non-economic factors such as residents' knowledge, attitudes, and practices for environmental protection have significant impacts on WTB. These non-economic factors can improve the residents' WTB by providing environmental education to residents through television and other modes of communication. This will reduce the subsidy rate and enhance the sustainability of the CBP project.

However, this study still has several limitations that require attention. First, the survey regions are mainly concentrated in five counties in Hebei and Shandong, but this paper wants to express WTU/WTB for the whole Hebei Province, Shandong Province, and even the whole NCP. Therefore, if expanding the scope of the research, the results may be more accurate and convincing. Secondly, the occupational structure, income source structure, and herd effect of rural residents may also be important factors influencing rural residents' decision-making. These factors will be further developed in future research. In addition, the double-bounded dichotomous choice method is a very mature method with its strengths and weaknesses. Maybe it will be interesting to test the results estimates by using the choice experiments (CE) method in other regions with similar socio-economic characteristics.

Author Contributions: All authors were involved in preparing the manuscript. Conceptualization, Q.W., T.D. and C.Y.; methodology, Q.W.; software, Q.W.; validation, Q.W., C.Y. and G.W.; formal analysis, Q.W. and X.H.; investigation, Q.W. and X.H.; resources, C.Y. and G.W.; data curation, Q.W.; writing-original draft preparation, Q.W. and T.D.; writing-review and editing, Q.W., T.D., C.Y. and X.H.; visualization, Q.W.; supervision, C.Y. and T.D.; project administration, Q.W. and G.W.; funding acquisition, C.Y.

Funding: This research was funded by Major Program of National Social Science Foundation of China (18ZDA048), China Agriculture Research System-Green Manure (CARS-22-G25).

Conflicts of Interest: No potential conflict of interest was reported by the authors.

\section{Abbreviations/Nomenclature}

$\begin{array}{ll}\text { Abbreviations } & \text { Explanation } \\ \text { NCP } & \text { North China Plain } \\ \text { WTPA } & \text { Willingness to Participate } \\ \text { WTB } & \text { Willingness to Buy } \\ \text { CVM } & \text { Contingent Valuation Method } \\ \text { CBP } & \text { Centralized Biogas Production } \\ \text { KAP } & \text { Knowledge, Attitude, Practice } \\ \text { CNY } & \text { Chinese Yuan (¥) } \\ \text { OLS } & \text { Ordinary Least Square }\end{array}$

\section{References}

1. Yang, X.; Cheng, L.; Yin, C.; Lebailly, P.; Azadi, H. Urban residents' willingness to pay for corn straw burning ban in Henan, China: Application of payment card. J. Clean. Prod. 2018, 193, 471-478. [CrossRef]

2. Wei, Y.; Liao, H.; Wang, K. China Energy Report (2014): Energy Poverty Study; Chinese Science Publisher: Beijing, China, 2014; pp. 103-125. (In Chinese)

3. Wang, H.; Wang, Y.; Gao, C.; Wang, D.; Qin, C.; Bi, Y. Environmental impact assessment of straw biogas centralized gas supply project based on LCA. Trans. CSAE 2017, 33, 237-243, (in Chinese with English abstract).

4. National Bureau of Statistics China Rural Poverty Monitoring Report 2017; China Statistics Press: Beijing, China, 2018. (In Chinese)

5. Cong, H.; Zhao, L.; Meng, H.; Yao, Z.; Huo, L.; Jia, J.; Wu, Y. Applicability evaluation of biomass pyrolytic poly-generation technology on clean heating in northern rural of China. Trans. Chin. Soc. Agric. Eng. 2018, $34,8-14$.

6. GOSC. Three-year Action Plan for the Renovation of Rural Human Settlements Environment; General Office of the State Council (GOSC): Beijing, China, 2018. 
7. NEA. Notice on the Construction of Clean Heating Demonstration Project of "100 Towns" Biomass Cogeneration County; National Energy Administration (NEA): Beijing, China, 2018.

8. NDRC. Winter Clean Heating Planning in the North (2017-2021) (2017-12-05); National Development and Reform Commission (NDRC): Beijing, China, 2018. (In Chinese)

9. Xi, J. Winning a Comprehensive Well-Off Society and Winning a Great Victory in Socialism with Chinese Characteristics in the New Era; People's Publishing House of China: Beijing, China, 2017. (In Chinese)

10. NDRC; MOA. Guidance Opinions on Construction of Centralized Gas Supply and Utilization Project for Straw Gasification and Biomass Gasification; National Development and Reform Commission (NDRC); Ministry Of Agriculture (MOA): Beijing, China, 2017. (In Chinese)

11. NDRC; NEA. Guidance on Promoting the Development of Biomass Heat Supply ([2017]2123); National Development and Reform Commission (NDRC); National Energy Administration (NEA): Beijing, China, 2017. (In Chinese)

12. Achinas, S.; Achinas, V.; Euverink, G.J.W. A Technological Overview of Biogas Production from Biowaste. Engineering 2017, 3, 299-307. [CrossRef]

13. Du, T.; Yun, S.; Zhu, J.; Huang, X. Research progress of anaerobic fermentation of biomass waste. China Biogas 2016, 34, 46-52.

14. Achinas, S.; Krooneman, J.; Euverink, G.J.W. Enhanced Biogas Production from the Anaerobic Batch Treatment of Banana Peels. Engineering 2019, 5, 970-978. [CrossRef]

15. Achinas, S.; Euverink, G.J.W. Elevated biogas production from the anaerobic co-digestion of farmhouse waste: Insight into the process performance and kinetics. Waste Manag. Res. 2019, 37, 1240-1249. [CrossRef]

16. Rasapoor, M.; Young, B.; Brar, R.; Sarmah, A.; Zhuang, W.Q.; Baroutian, S. Recognizing the challenges of anaerobic digestion: Critical steps toward improving biogas generation. Fuel 2020, 261, 116497. [CrossRef]

17. Fazal, T.; Saif Ur Rehman, M.; Mushtaq, A.; Hafeez, A.; Javed, F.; Aslam, M.; Fatima, M.; Faisal, A.; Iqbal, J.; Rehman, F.; et al. Simultaneous production of bioelectricity and biogas from chicken droppings and dairy industry wastewater employing bioelectrochemical system. Fuel 2019, 256, 115902. [CrossRef]

18. Peppers, J.; Li, Y.; Xue, J.; Chen, X.; Alaimo, C.; Wong, L.; Young, T.; Green, P.G.; Jenkins, B.; Zhang, R.; et al. Performance analysis of membrane separation for upgrading biogas to biomethane at small scale production sites. Biomass Bioenergy 2019, 128, 105314. [CrossRef]

19. Adnan, A.I.; Ong, M.Y.; Nomanbhay, S.; Chew, K.W.; Show, P.L. Technologies for Biogas Upgrading to Biomethane: A Review. Bioengineering 2019, 6, 92. [CrossRef] [PubMed]

20. Schmid, C.; Horschig, T.; Pfeiffer, A.; Szarka, N.; Thrän, D. Biogas Upgrading: A Review of National Biomethane Strategies and Support Policies in Selected Countries. Energies 2019, 12, 3803. [CrossRef]

21. Patinvoh, R.J.; Taherzadeh, M.J. Challenges of biogas implementation in developing countries. Curr. Opin. Environ. Sci. Health 2019, 12, 30-37. [CrossRef]

22. Yuyun, B. Straw Resource Evaluation and Utilization Research. Ph.D. Thesis, Chinese Academy of Agricultural Sciences, Beijing, China, 2010. (in Chinese with English abstract).

23. Wang, L.; Gao, C.; Bi, Y.; Wang, Y.; Wang, H.; Sun, N.; Yu, J. Estimation of greenhouse gas emission reduction for large-scale straw biogas centralized gas supply project. Trans. CSAE 2017, 33, 223-228, (in Chinese with English abstract).

24. Jiang, L.; Zhang, J.; Wang, H.H.; Zhang, L.; He, K. The impact of psychological factors on farmers' intentions to reuse agricultural biomass waste for carbon emission abatement. J. Clean. Prod. 2018, 189, 797-804. [CrossRef]

25. Zhu, L.; Song, Q.; Sheng, N.; Zhou, X. Exploring the determinants of consumers' WTB and WTP for electric motorcycles using CVM method in Macau. Energy Policy 2019, 127, 64-72. [CrossRef]

26. Zemo, K.H.; Termansen, M. Farmers' willingness to participate in collective biogas investment: A discrete choice experiment study. Resour. Energy Econ. 2018, 52, 87-101. [CrossRef]

27. Kabyanga, M.; Balana, B.B.; Mugisha, J.; Walekhwa, P.N.; Smith, J.; Glenk, K. Are smallholder farmers willing to pay for a flexible balloon biogas digester? Evidence from a case study in Uganda. Energy Sustain. Dev. 2018, 43, 123-129. [CrossRef]

28. He, K.; Zhang, J.; Zeng, Y.; Zhang, L. Households' willingness to accept compensation for agricultural waste recycling: Taking biogas production from livestock manure waste in Hubei, P.R. China as an example. J. Clean. Prod. 2016, 131, 410-420. [CrossRef]

29. He, K.; Zhang, J.; Zeng, Y. Rural households' willingness to accept compensation for energy utilization of crop straw in China. Energy 2018, 165, 562-571. [CrossRef] 
30. Huang, X.; Cheng, L.; Chien, H.; Jiang, H.; Yang, X.; Yin, C. Sustainability of returning wheat straw to field in Hebei, Shandong and Jiangsu provinces: A contingent valuation method. J. Clean. Prod. 2019, 213, 1290-1298. [CrossRef]

31. Lee, C.; Heo, H. Estimating willingness to pay for renewable energy in South Korea using the contingent valuation method. Energy Policy 2016, 94, 150-156. [CrossRef]

32. Xie, B.; Zhao, W. Willingness to pay for green electricity in Tianjin, China: Based on the contingent valuation method. Energy Policy 2018, 114, 98-107. [CrossRef]

33. Ferreira, S.; Marques, R.C. Contingent valuation method applied to waste management. Resour. Conserv. Recycl. 2015, 99, 111-117. [CrossRef]

34. Fujii, S.; Kitamura, R.; Suda, H. Contingent valuation method can increase procedural justice. J. Econ. Psychol. 2004, 25, 877-889. [CrossRef]

35. Whitehead, J.C. Plausible responsiveness to scope in contingent valuation. Ecol. Econ. 2016, 128, 17-22. [CrossRef]

36. Brebner, S.; Sonnemans, J. Does the elicitation method impact the WTA/WTP disparity? J. Behav. Exp. Econ. 2018, 73, 40-45. [CrossRef]

37. Venkatachalam, L. The contingent valuation method: A review. Environ. Impact Assess. Rev. 2004, 24, 89-124. [CrossRef]

38. Briscoe, J.; de Castro, P.F.; Griffin, C.; North, J.; Olsen, O. Toward Equitable and Sustainable Rural Water Supplies: A Contingent Valuation Study in Brazil. World Bank Econ. Rev. 1990, 4, 115-134. Available online: http://www.jstor.org/stable/3989925 (accessed on 31 May 2009). [CrossRef]

39. Hanemann, C.O.; Gabreëls-Festen, A.A.W.M.; Stoll, G.; Muller, H.W. Schwann cell differentiation in Charcot-Marie-Tooth disease type 1A (CMT1A): Normal number of myelinating Schwann cells in young CMT1A patients and neural cell adhesion molecule expression in onion bulbs. Acta Neuropathol. 1997, 94, 310-315. [CrossRef]

40. Spash, C.L. Non-Economic Motivation for Contingent Values: Rights and Attitudinal Beliefs in the Willingness to Pay for Environmental Improvements. Land Econ. 2006, 82, 602-622. [CrossRef]

41. Chaudhry, P.; Singh, B.; Tewari, V.P. Non-market economic valuation in developing countries: Role of participant observation method in CVM analysis. J. For. Econ. 2007, 13, 259-275. [CrossRef]

42. Yang, X.; He, L.; Xia, Y.; Chen, Y. Effect of government subsidies on renewable energy investments: The threshold effect. Energy Policy 2019, 132, 156-166. [CrossRef]

43. Bolis, I.; Morioka, S.N.; Sznelwar, L.I. Are we making decisions in a sustainable way? A comprehensive literature review about rationalities for sustainable development. J. Clean. Prod. 2017, 145, 310-322. [CrossRef]

44. Amiran, E.Y.; Hagen, D.A. What do income tests tell us about the gap between WTA and WTP for public goods? J. Environ. Econ. Manag. 2018, 90, 134-146. [CrossRef]

45. Yuan, G.; Yang, W. Evaluating China's Air Pollution Control Policy with Extended AQI Indicator System: Example of the Beijing-Tianjin-Hebei Region. Sustainability 2019, 11, 939. [CrossRef]

46. Zheng, Z.; Yang, Z.; Wu, Z.; Marinello, F. Spatial Variation of NO2 and Its Impact Factors in China: An Application of Sentinel-5P Products. Remote Sens. 2019, 11, 1939. [CrossRef]

47. Fan, H.; Zhao, C.; Yang, Y. A comprehensive analysis of the spatio-temporal variation of urban air pollution in China during 2014-2018. Atmos. Environ. 2020, 220, 117066. [CrossRef]

48. Su, P.; Lin, D.; Qian, C. Study on Air Pollution and Control Investment from the Perspective of the Environmental Theory Model: A Case Study in China, 2005-2014. Sustainability 2018, 10, 2181. [CrossRef]

49. Jin, Y.; Andersson, H.; Zhang, S. Air Pollution Control Policies in China: A Retrospective and Prospects. Int. J. Environ. Res. Public Health 2016, 13, 1219. [CrossRef]

50. Zhang, D.; Liu, J.; Li, B. Tackling Air Pollution in China-What do We Learn from the Great Smog of 1950s in LONDON. Sustainability 2014, 6, 5322-5338. [CrossRef]

51. Song, D.; Hou, S.; Wang, X.; Liang, G.; Zhou, W. Nutrient resource quantity of crop straw and its potential of substituting. J. Plant Nutr. Fertil. 2018, 24, 1-21.

52. China Agricultural Statistics Yearbook Editorial Board. China Agricultural Statistics Yearbook; China Agricultural Press: Beijing, China, 2017; p. 183. (In Chinese)

53. Kaliyaperumal, K. Guideline for conducting a knowledge, attitude and practice (KAP) study. AECS Illum. 2004, 4, 7-9. 
54. Ahamad, N.R.; Ariffin, M. Assessment of knowledge, attitude and practice towards sustainable consumption among university students in Selangor, Malaysia. Sustain. Prod. Consum. 2018, 16, 88-98. [CrossRef]

55. Almasi, A.; Mohammadi, M.; Azizi, A.; Berizi, Z.; Shamsi, K.; Shahbazi, A.; Mosavi, S.A. Assessing the knowledge, attitude and practice of the kermanshahi women towards reducing, recycling and reusing of municipal solid waste. Resour. Conserv. Recycl. 2019, 141, 329-338. [CrossRef]

56. Vandamme, E. Concepts and Challenges in the Use of Knowledge-Attitude-Practice Surveys: Literature Review; Institute of Tropical Medicine: Antwerp, Belgium, 2009.

57. Flachaire, E.; Hollard, G. Starting point bias and respondent uncertainty in dichotomous choice contingent valuation surveys. Resour. Energy Econ. 2007, 29, 183-194. [CrossRef]

58. Xie, B.; Zhao, W.; Yin, Z.; Xie, P. How much will the residents pay for clean energy? Empirical study using the double bound dichotomous choice method for Tianjin, China. J. Clean. Prod. 2019, 241, 118208. [CrossRef]

59. Yoon, T.; Ma, Y.; Rhodes, C. Individual Heating systems vs. District Heating systems: What will consumers pay for convenience? Energy Policy 2015, 86, 73-81. [CrossRef]

60. Miao, Y.; Yang, Z.; Zhou, H. Study on the Willingness to Pay and the Influencing Factors of Rural Residents' Environmental Health Improvement-Taking the Reform of Toilet as an Example. Manag. World 2012, 09, 89-99. (In Chinese) [CrossRef]

61. Heckman, J.J. Sample Selection Bias as a Specification Error. Econom. J. Econom. Soc. 1979, 47, $153-161$. [CrossRef]

62. Whittington, D.; Briscoe, J.; Mu, X.; Barron, W. Estimating the Willingness to Pay for Water Services in Developing Countries: A Case Study of the Use of Contingent Valuation Surveys in Southern Haiti. Econ. Dev. Cult. Chang. 1990, 38, 293-311. [CrossRef]

63. Harrison, D.A.; McLaughlin, M.E. Structural properties and psychometric qualities of organizational self-reports: Field tests of connections predicted by cognitive theory. J. Manag. 1996, 22, 313-338. [CrossRef]

64. Sutton, S. Health Behavior: Psychosocial Theories. In International Encyclopedia of the Social E Behavioral Sciences; Smelser, N.J., Baltes, P.B., Eds.; Pergamon: Oxford, UK, 2001; pp. 6499-6506.

65. Good, N. Using behavioural economic theory in modelling of demand response. Appl. Energy 2019, 239, 107-116. [CrossRef]

66. Hassani, H.; Sattar, M.; Odulaja, A.; Santoso, W.M. A statistical approach for a fuel subsidy mechanism. Energy Policy 2018, 119, 666-673. [CrossRef]

67. National Bureau of Statistics. Chinese Statistical Yearbook; China Statistics Press: Beijing, China, 2018 ; p. 183. (In Chinese)

68. Padilla-Rivera, A.; Paredes, M.G.; Güereca, L.P. A systematic review of the sustainability assessment of bioenergy: The case of gaseous biofuels. Biomass Bioenergy 2019, 125, 79-94. [CrossRef]

69. Shih, H.; Cheng, C.; Chen, H. Recycling fund management for a cleaner environment through differentiated subsidy rates. J. Clean. Prod. 2019, 240, 118146. [CrossRef]

70. Shen, J.; Luo, C. Overall review of renewable energy subsidy policies in China-Contradictions of intentions and effects. Renew. Sustain. Energy Rev. 2015, 41, 1478-1488. [CrossRef]

71. Lam, P.T.I.; Law, A.O.K. Financing for renewable energy projects: A decision guide by developmental stages with case studies. Renew. Sustain. Energy Rev. 2018, 90, 937-944. [CrossRef]

72. Newell, R.G.; Pizer, W.A.; Raimi, D.U.S. federal government subsidies for clean energy: Design choices and implications. Energy Econ. 2019, 80, 831-841. [CrossRef]

73. Eichner, T.; Pethig, R. EU-type carbon regulation and the waterbed effect of green energy promotion. Energy Econ. 2019, 80, 656-679. [CrossRef]

74. Zeng, Y.; Zhang, J.; He, K. Effects of conformity tendencies on households' willingness to adopt energy utilization of crop straw: Evidence from biogas in rural China. Renew. Energy 2019, 138, 573-584. [CrossRef]

75. Zou, B.; Luo, B. Rural household energy consumption characteristics and determinants in China. Energy 2019, 182, 814-823. [CrossRef]

76. National Health and Family Planning Commission. Report on the Family Development in China, 2015; Chinese Population Press: Beijing, China, 2015. (In Chinese)

77. Wu, S.; Zheng, X.; You, C.; Wei, C. Household energy consumption in rural China: Historical development, present pattern and policy implication. J. Clean. Prod. 2019, 211, 981-991. [CrossRef]

78. Ma, W.; Zhou, X.; Renwick, A. Impact of off-farm income on household energy expenditures in China: Implications for rural energy transition. Energy Policy 2019, 127, 248-258. [CrossRef] 
79. Zheng, G. Shandong Provincial Government Work Report; General Office of Shandong Provincial Government: Jinan, China, 2019.

80. Qin, X. Hebei Provincial Government Work Report; General Office of Hebei Provincial Government: Shijiazhuang, China, 2019.

81. Babaei, A.A.; Alavi, N.; Goudarzi, G.; Teymouri, P.; Ahmadi, K.; Rafiee, M. Household recycling knowledge, attitudes and practices towards solid waste management. Resour. Conserv. Recycl. 2015, 102, 94-100. [CrossRef]

82. Nguyen, T.P.L.; Seddaiu, G.; Roggero, P.P. Declarative or procedural knowledge? Knowledge for enhancing farmers' mitigation and adaptation behaviour to climate change. J. Rural Stud. 2019, 67, 46-56. [CrossRef]

83. Singh, S.K.; Chen, J.; Del Giudice, M.; El-Kassar, A. Environmental ethics, environmental performance, and competitive advantage: Role of environmental training. Technol. Forecast Soc. 2019, 146, 203-211. [CrossRef]

84. Varela-Candamio, L.; Novo-Corti, I.; Teresa Garcia-Alvarez, M. The importance of environmental education in the determinants of green behavior: A meta-analysis approach. J. Clean. Prod. 2018, 170, 1565-1578. [CrossRef]

85. Chen, Q.; Liu, T. Biogas system in rural China: Upgrading from decentralized to centralized? Renew. Sustain. Energy Rev. 2017, 78, 933-944. [CrossRef]

86. Yin, D.; Liu, W.; Zhai, N.; Wang, Y.; Ren, C.; Yang, G. Regional differentiation of rural household biogas development and related driving factors in China. Renew. Sustain. Energy Rev. 2017, 67, 1008-1018. [CrossRef]

87. GOSC. Air Pollution Prevention Action Plan; General Office of the State Council (GOSC), GOSC: Beijing, China, 2013.

(C) 2019 by the authors. Licensee MDPI, Basel, Switzerland. This article is an open access article distributed under the terms and conditions of the Creative Commons Attribution (CC BY) license (http://creativecommons.org/licenses/by/4.0/). 